\title{
Study on New Medial Application in College Ideological and Political Education
}

\author{
Zhongheng Luan \\ School of Marxism, Haikou College of Economics, Haikou Hainan, 570228, China
}

Key words: College, Ideological and political education, New media.

\begin{abstract}
In recent years, social media represented by microblog and WeChat have become the ideal way for communication. Nowadays, the scale of netizens in China has broken through 600 million, where mobile phone netizens are in the majority. College students are a large-scale group among the netizens. New media are driving college students to change their ideas, values and even life style. The application of new media in college ideological and political education has great development potential. This paper ideological and political educations basic features of new media, discusses the main effects of new media on college ideological and political education and proposes countermeasures to apply new media technology in college ideological and political education.
\end{abstract}

\section{Introduction}

In view of rapid development of modern science and technology, new media technology has penetrated in numerous aspects of society, which brought great influence people's life, learning and working modes. College students have great curiosity for anything new, and they can accept and well apply new media resources fast. Meanwhile, they can acquire all kinds of information they need through new media. New media offer a good self-development and self-exhibition stage for college students. Ideology, thinking mode and behavioral pattern of college students will be greatly influenced by new media. In addition, new media will lead to huge pressure and challenge to college ideological and political education. Under such background, college ideological and political education workers should actively innovate the methods of ideological and political education, enhance ideological and political education through new media technology and practically improve practical effect of ideological and political education.

\section{Basic features of new media}

Because of era development and technical progress, new media with diversified forms derive fast, mainly including microblog and WeChat. These new media not merely bring great convenience for people in modern life, but enrich people's communication form. New media regards network technology as the important foundation and embody the new features widely different from traditional media. The new features are mainly reflected in three aspects: firstly, good interactivity. Information communication forms of new media are diversified, and new media can break space-time restrictions of traditional media. Through new media platform, each user is an equal individual and can express his opinions freely. Besides, users can communicate and interact with many people at the same time. Secondly, timeliness. In terms of information communication, new media can rapidly communicate and update information as well as offer more efficient information service for modern people. Thirdly, virtuality. New media further embody information communication mode and achieve information communication through digitization and virtualization of information carrier. In the virtual environment created by new media, users' personal information can be well protected. This has great significance for ideological and political education of college students and can well 
stimulate interactions between teachers and students. The features of new media have been accepted and favored by college students and applied in quantity in practice.

\section{Main influence of new media on college ideological and political education}

Firstly, new media bring challenges for traditional college traditional ideological and political education. Based on new media environment, new media represented by microblog and WeChat have gone deep into all aspects of learning and life of contemporary college students, which leads to great influence in the thought and behaviors of college students. The appearance of new media offers great convenience for extensive and fast information communication. Very abundant network resources can continuously expand the view of college students and offer the space and platform for their independent learning. Hence, new media can improve the subjectivity of college students and actively encourage them to give full play to their subjective initiative in ideological and political education. Meanwhile, complexity and diversity of network information also bring large challenges to college ideological and political education. The quantity of all kinds of false information and unhealthy information is striking. College students are in the key period of forming view on life and values, so they may be easily influenced by bad information. This gives rise to passive effects on ideological and political education and goes against effective implementation of ideological and political education.

Secondly, new media set up a new platform for implementation of college ideological and political education. The application of new media technology in college ideological and political education offers a new platform for teachers to comprehensive understand college students. Communication between teachers and students can be enhanced through using new media technology. Teachers can know ideological situation of college students anytime and then find their ideological and psychological problems. Besides, teachers can take effective measures to help and guide college students to form correct values. For example, each class of colleges will establish QQ group and WeChat group. If the instructor and teachers can join, they can well know students' dynamic state, enhance guidance of them in ideological and political education, enhance emotion between teachers and students, and improve teamwork awareness.

Thirdly, good ideological and political education resources can be offered for college students. Previous ideological and political education mode was too single. The teaching contents were arranged completely according to teaching materials and lacked innovation. Besides, the content of ideological and political education could not be well combined with detailed situations of college students. This seriously restricted the effect of ideological and political education. Based on new media environment, ideological and political education workers can utilize new media technology to screen learning materials and cases suitable for college students so as to make the content of ideological and political education richer and improve students' learning initiative. Of course, new media can further enrich the mode and method of ideological and political education, improve traditional education mode and enhance effect of college ideological and political education.

\section{Countermeasures to apply new media technology in college ideological and political education}

\section{To establish new idea of college ideological and political education}

To better apply ideological and political education to improve the effect of ideological and political education, it is required to change inherent idea of ideological and political education workers, let them realize the positive effect of new media on college ideological and political education, know huge potential of new media technology, encourage college ideological and political education workers to combine specific work of ideological and political education and new media technology and form favorable view on ideological and political education. New media may be applied in college ideological and political education to give play to subjectivity function of college students, mobilize their enthusiasm, make them take active part in ideological and political education and let traditional 
cramming education become new bi-directional interactive education. In this way, the equal relation between teachers and students can be established, and practical effect of college ideological and political education can improve greatly.

\section{To build new media communication base for ideological and political education}

New media communication base mainly refers to virtual cluster and virtual community by uniting individual users based on virtual of new media. First of all, it is required to intensify official microblog and WeChat public number building of colleges, form good online image and establish official new media cluster so as to become a new carrier of ideological and political education. Colleges can establish special QQ group and WeChat group for ideological and political education so as to create a new platform for experience exchange and resource sharing about ideological and political work. In addition, students' affairs office, teaching affairs office or political parties etc, may also establish microblog group and WeChat group, and improve guidance of ideological and political education when releasing contents. For example, some college young volunteer societies apply microblog to communicate relevant information for public welfare, guide college students to pay more attention to social public welfare, and train their sprit of dedication and mutual assistance. Moreover, the positive role of college student backbones should be exerted, and activists should be absorbed $\mathrm{t}$ take active part in building new media communication base for ideological and political education. Information content published by official media should be closer to psychology of college students.

\section{To apply new media tp improve traditional ideological and political education mode}

As the era of new media arrives, new media greatly enrich extracurricular life of contemporary college students and bring good life and learning experience for them. Compared with traditional teaching mode, contemporary college students are more keen on the education mode based on new media. New media become a bond which connects teachers and students by virtue of strong interactivity ability. Through new media, teachers can know students' practical thoughts more comprehensively and then implement oriented guidance and education so as to greatly improve the effect of ideological and political education. College ideological and political education workers must overall apply new media to innovate the specific mode and method of ideological and political education so as to achieve all-round and deep communication with college students. For instance, teachers may create personal WeChat and microblog, add each student in the circle of friends, care about students; dynamic changes and let students share their experience. In this way, equal and harmonious relationship between teachers and students can form, and ideological and political education can penetrate in daily life. In addition, teachers can apply new media to create a communication platform for the class, offer college students with the opportunity and space for free talks and actively encourage college students to participate in class building so as to cultivate their sense of group honor and cooperation and give full play to their subjective initiative and advantages. This has very positive function for driving people-oriented education.

\section{To well apply new functions of new media such as guidance and public opinion control}

The instantaneity and rapidness features of new media can practically speed up public opinion communication, expand the influence scope of public opinions and shorten the communication period of public opinions. Meanwhile, they facilitate communication of all kinds of unhealthy information. Colleges and ideological and political education workers should draw on advantages, avoid disadvantages, and apply advantages of new media to continuously enhance ideological guidance and public opinion control. Firstly, it is required to improve new media management system for ideological and political education. Colleges can bring new media management in daily work of network center, continuously intensify network security maintenance and prevent unhealthy information from entering the application terminal. If unhealthy information appears, it is required to public accurate information fast to master the initiative of public opinion, except stopping the unhealthy information technically. Secondly, new media should be applied properly to release the 
contents which can embody social mainstream ideology so as to create a public opinion development platform with more distinct value orientation which teachers and students take active part in. In terms of content editing, relevant skills should be applied well to avoid theoretical brag and polite formula and really change inflexible teaching mode of traditional ideological and political education. Thirdly, new media can be applied to enrich ideological and political education and enhance ideological guidance and public opinion guidance functions. For example, multimedia technology can be used to play relevant videos and pictures, which can well enhance attraction of teaching content. Of course, ideological and political theoretical course can be taught online, and teachers can be organized for online answering questions so a to improve the effect of ideological and political education.

\section{To improve new media operation ability of college ideological and political education workers}

In the era of new media, talent team of college ideological and political education should expand continuously. For example, network information personnel, technical maintenance personnel and ideological and political education personnel should take part in college ideological and political education system so as to build talent team with fighting capacity. This is an inexorable trend of era development. Firstly, training and external communication should be applied to improve the ability of ideological and political education workers to new media and marketing ability, mainly including the ability to understand, analyze and evaluate network information with network knowledge and skills, network moral accomplishment and legal consciousness. Secondly, the application situation of new media should be added in teacher performance appraisal system, and competitive mode can be applied to promote college teachers to use new media in teaching practice. Thirdly, inter-disciplinary talent introduction should be enhanced. In particular, high-quality talents who are proficient in modern network technology, news and college student management should be introduced. Preferential policy should be formulated to attract high-level talents, and traditional employment limitation should be broken. It is required to expand talent introduction approaches, break through inherent identity limitation, and only employ the talented persons so as to effectively improve the effect of college ideological and political education.

\section{Conclusions}

In one word, new media technology has been well applied in current college ideological and political education, because of its prominent advantages such as rich expression forms, great interactivity and huge information resources. Furthermore, it plays a greater and greater role. Full application of new media in higher education quite complies with the features of contemporary college students. As long as new media technology is applied properly, colleges will be bound to yield twofold results with half efforts. Then, new development of college ideological and political education can be promoted.

\section{References}

[1] Zheng Yan, Opportunity and challenge of college ideological and political education in new media era, Theory Research, 2015 (1).

[2] Sun Xun, Study on innovation of college ideological and political education method under new media environment, Modern Communication, 2015 (11).

[3] Qiu Yan, Strategy of optimizing college ideological and political education method under new media environment, School Party Building and Ideological Education, 2015 (24).

[4] Cai Cui, Analysis of college ideological and political education method in new media era, Knowledge Economy, 2016 (2).

[5] Yang Bo, Qin Qi, Optimization of college ideological and political education in new media era, Social Sciences Journal of Colleges of Shanxi, 2016 (6). 
[6] Meng Yu, Study on college ideological and political education in new media era, Journal of Hubei University of Economics(Humanities and Social Sciences), 2016 (6). 